\title{
BENTUK - BENTUK TIDAK PATUHAN TERGUGAT TERHADAP PUTUSAN YANG TELAH MEMPUNYAI KEKUATAN HUKUM TETAP
}

\author{
Fadel Bimawanpati \\ Email : fadelbimawanpati22@gmail.com \\ No BP : 2010003600284 \\ Universitas Ekasakti Padang
}

\section{A. PENDAHULUAN}

Sebagai negara yang demokratis, Indonesia memiliki sistem ketatanegaraan dengan memiliki lembaga eksekutif, legislatif dan yudikatif. Dari ketiga lembaga tersebut eksekutif memiliki porsi peran dan wewenang yang paling besar apabila dibandingkan dengan lembaga lainnya, oleh karenanya perlu ada kontrol terhadap pemerintah untuk adanya check and balances. Untuk mengontrol kekuasaan eksekutif tersebut diperlukan lembaga yudikatif atau kehakiman. Berkaitan dengan kekuasaan kehakiman dalam Pasal 24 UUD 1945 jo. UndangUndang No. 4 Tahun 2004 menyatakan bahwa kekuasaan kehakiman dilaksanakan oleh sebuah Mahkamah Agung dan badan-badan peradilan yang berada di bawahnya dalam lingkungan peradilan umum, lingkungan peradilan agama, lingkungan peradilan militer, lingkungan peradilan tata usaha negara dan oleh sebuah Mahkamah Konstitusi.3 Lahirnya Peradilan Tata Usaha Negara dapat disimpulkan merupakan tuntutan masyarakat Indonesia yang merasa haknya sebagai warga negara dilanggar oleh pemerintah, selain itu untuk mencegah terjadinya maladministrasi, serta segala bentuk penyalahgunaan wewenang oleh pemerintah. Sebagai negara yang berdasarkan atas hukum (rechtsstaat) tentunya tindakan dari pemerintah tersebut harus berdasarkan ketentuan hukum yang berlaku. Dibutuhkan suatu pengujian yuridis terhadap tindakan pemerintah dan pengujian yang dilakukan terhadap 
tindakan pemerintah itu harus dapat menghasilkan perlindungan bagi kepentingan rakyat. Apabila tindakan tersebut bertentangan dengan kepentingan rakyat, maka kepentingan rakyat tidak semena-mena dapat dikorbankan begitu saja. Dengan kewenangan yang besar dan luas menimbulkan potensi penyelewenangan seperti "abuse of power" dan "excessive power" sehingga dibutuhkan pengawasan yang serius dalam hal ini.

Apabila sengketa Tata Usaha Negara tersebut di atas timbul, maka penyelesaian sengketanya dapat ditempuh melalui Peradilan Tata Usaha Negara sebagai salah satu sarana Hukum bagi rakyat (masyarakat) di Indonesia. Namun persoalannya adalah bagaimanakah fungsi pengawasan yustisial oleh Peradilan Tata Usaha Negara mampu secara efektif dapat dilaksanakan dalam hubungannya dengan pelaksanaan otonomi daerah oleh karena itu dikaitkan dengan proses penyelesaian sengketa Tata Usaha Negara, dimana tahap akhir dalam proses penyelesaian sengketa Tata Usaha Negara Pengadilan Tata Usaha Negara adalah eksekusi atau pelaksanaan Putusan Pengadilan Tata Usaha Negara yang telah berkekuatan Hukum tetap. Eksekusi mengandung makna pelaksanaan putusan oleh atau dengan bantuan pihak lain diluar para pihak yang bersengketa. Hakekat dari eksekusi tidak lain ialah realisasi dari pada kewajiban pihak yang bersangkutan untuk memenuhi prestasi yang tercantum didalam Putusan tersebut.Hanya putusan pengadilan yang telah berkekuatan hukum tetap yang dapat dilaksanakan. Namun, tak semua pihak yang dikalahkan bersedia secara sukarela menjalankan putusan hakim. Dalam perkara pidana dan perdata, aparat penegak hukum yang akan melaksanakan eksekusi putusan bisa meminta bantuan aparat keamanan. Beda halnya dengan eksekusi putusan PTUN, dalam eksekusi putusan PTUN tidak dimungkinkan upaya paksa dengan menggunakan aparat keamanan. Istimewanya, Presiden selaku kepala pemerintahan dimungkinkan campur tangan dalam pelaksanaan putusan PTUN. 


\section{B. PEMBAHASAN}

Peradilan Tata Usaha Negara merupakan pelaksana kekuasaan kehakiman yang ditugaskan untuk memeriksa, memutus, dan menyelesaikan sengketa tersebut akan berhadapan dengan Badan atau Pejabat Tata Usaha Negara dengan atau badan hukum perdata, akibat dikeluarkannya suatu putusan Tata Usaha Negara yang dianggap melanggar hak orang atau badan hukum perdata. Peradilan Tata Usaha Negara terbentuk 5 (lima) tahun setelah dikeluarkan dan disahkannya Undang-Undang Nomor 5 Tahun 1986 yang kemudian terjadi dua kali perubahan yaitu Undang-Undang Nomor 9 Tahun 2004 tentang Perubahan Atas Undang-Undang Nomor 5 Tahun 1986 tentang Peradilan Tata Usaha Negara, dan UndangUndang Nomor 51 Tahun 2009 tentang Perubahan Kedua Atas UndangUndang Nomor 5 Tahun 1986 Tentang Peradilan Tata Usaha Negara. Pembentukan Peradilan Tata Usaha Negara dimaksudkan untuk menyelesaikan sengketa antara pemerintah dengan warga negara. Dalam hal ini sengketa yang ditimbulkan sebagai akibat adanya tindakan-tindakan pemerintah yang melanggar hak-hak dari warga negara. Peradilan Tata Usaha Negara antara lain juga berfungsi untuk mendorong kehatihatian administrasi negara maupun untuk melindungi segala kepentingan rakyat, individu maupun masyarakat dari berbagai tindakan sewenang-wenang, melampaui kewenangan, kecerobohan, keberpihakan secara tidak fair oleh Badan atau Pejabat Tata Usaha Negara.

Eksekusi putusan PTUN tidak dimungkinkan upaya paksa dengan menggunakan aparat keamanan. Istimewanya, Presiden selaku kepala pemerintahan dimungkinkan campur tangan dalam pelaksanaan putusan PTUN.

Putusan PTUN yang telah berkekuatan hukum tetap, sejalan dengan Pasal 97 ayat (8) dan ayat (9) UU PTUN, pada dasarnya dapat berupa: 
- Batal atau tidak sah Keputusan Tata Usaha Negara ("KTUN") yang menimbulkan sengketa dan menetapkan Badan/Pejabat TUN yang mengeluarkan keputusan untuk mencabut KTUN dimaksud. Paulus Effendi Lotulung menyebutnya sebagai eksekusi otomatis. Jika putusan TUN tidak dipatuhi maka KTUN tersebut tidak mempunyai kekuatan hukum lagi, tidak perlu lagi ada tindakan atau upaya lain dari pengadilan seperti surat peringatan (R. Wiyono, 2009: 234).

- Pelaksanaan putusan pengadilan yang dimaksud dalam Pasal 97 ayat (9) huruf b, yang mewajibkan pejabat TUN bukan hanya mencabut tetapi juga menerbitkan KTUN baru.

- Selain itu, ada juga putusan yang mengharuskan pejabat TUN menerbitkan KTUN sebagaimana dimaksud Pasal 3 UU PTUN. Pasal 3 mengatur tentang keputusan fiktif negative.

Pembentuk Undang-Undang mengharapkan Badan/Pejabat TUN melaksanakan putusan secara sukarela. Namun, keberhasilan pelaksanaan putusan itu sangat bergantung pada wibawa. Kalau putusan yang sudah berkekuatan hukum tetap tidak dijalankan juga, maka UU PTUN menyediakan mekanisme berupa sanksi administratif dari atasan Badan/Pejabat TUN bersangkutan. Lewat ancaman sanksi itu, atasan pejabat yang mengeluarkan KTUN pada dasarnya sedang melakukan upaya paksa.

Mekanisme lain yang disebut dalam UU PTUN adalah pengenaan uang paksa dan pengumuman lewat media massa. Pasal 116 ayat (5) UU PTUN menyatakan pejabat yang tidak melaksanakan putusan Pengadilan diumumkan pada media massa cetak setempat oleh panitera sejak tidak terpenuhinya batas waktu 90 hari kerja. Begitu batas waktu lewat, penggugat mengajukan permohonan kepada ketua pengadilan agar tergugat melaksanakan putusan. Pasal 116 ayat (6) UU PTUN menegaskan lebih lanjut, ketua pengadilan 
mengajukan ketidakpatuhan ini kepada Presiden sebagai pemegang kekuasaan pemerintahan tertinggi dan kepada DPR untuk menjalankan fungsi pengawasan. Dari rumusan ini jelas bahwa Presiden punya kewenangan memaksa pejabat TUN untuk melaksanakan putusan.

Sedangkan, mekanisme uang paksa yang disebut dalam Pasal 116 ayat (4) UU PTUN, hingga kini regulasinya belum jelas. Penjelasan Pasal 116 ayat (4) UU PTUN hanya menyebutkan pembebanan berupa pembayaran sejumlah uang dicantumkan dalam amar putusan pada saat hakim memutuskan mengabulkan gugatan penggugat. Setidaknya, masih menjadi pertanyaan apakah uang paksa itu digabung bersama gugatan ke PTUN atau terpisah, siapa yang harus membayar (pribadi pejabat TUN atau dari anggaran badan), dan berapa besar uang paksa atau dwangsom yang dimungkinkan. Ini masalah krusial yang sering ditanyakan dan tampaknya perlu segera diatasi (Mahkamah Agung, 2007: 9).

Sanksi Hukum Administrasi, menurut J.B.J.M. ten Berge, ”sanksi merupakan inti dari penegakan hukum administrasi. Sanksi diperlukan untuk menjamin penegakan hukum administrasi". Menurut P de Haan dkk, "dalam HAN, penggunaan sanksi administrasi merupakan penerapan kewenangan pemerintahan, dimana kewenangan ini berasal dari aturan hukum administrasi tertulis dan tidak tertulis". JJ. Oosternbrink berpendapat "sanksi administrasi adalah sanksi yang muncul dari hubungan antara pemerintah-warga negara dan yang dilaksanakan tanpa perantara pihak ketiga (kekuasaan peradilan), tetapi dapat secara langsung dilaksanakan oleh administrasi sendiri”.5 Jenis Sanksi Administrasi dapat dilihat dari segi sasarannya yaitu sanksi reparatoir artinya sanksi yang diterapkan sebagai reaksi atas pelanggaran norma, yang ditujukan untuk mengembalikan pada kondisi semula sebelum terjadinya pelanggaran, misalnya bestuursdwang, dwangsom, sanksi punitif artinya sanksi yang ditujukan untuk memberikan hukuman pada seseorang, misalnya adalah berupa denda administratif, sedangkan Sanksi Regresif adalah sanksi yang diterapkan sebagai reaksi atas ketidakpatuhan terhadap ketentuan yang terdapat pada ketetapan yang diterbitkan. 
Dalam kenyataannya, meskipun putusan pengadilan TUN telah memiliki kekuatan hukum tetap, bukan berarti keputusannya akan dapat dilaksanakan semudah itu. Tidak semua orang yang dikenai putusan akan mau melaksanakan putusan ini sehingga kadangkadang diperlukan upaya paksa, dalam hal ini aparat keamanan. Akan tetapi dalam pelaksanaan putusan PTUN, keberadaan aparat keamanan tidak dimungkinkan. Yang memungkinkan adalah campur tangan presiden sebagai kepala pemerintahan dalam rangka memaksa. Beberapa kendalanya adalah:

1. Tidak adanya lembaga eksekutorial khusus atau lembaga sanksi yang berfungsi untuk melaksanakan putusan. Peradilan Umum memiliki lembaga paksa, yakni eksekusi riil oleh Kepaniteraan dibawah pimpinan Ketua Pengadilan untuk perkara perdata (Pasal 195 s/d Pasal 208 HIR dan Pasal 1033 Rv), dan ada jaksa sebagai eksekutor putusan Pidana (Pasal 270 KUHAP). Di peradilan Militer adalah Oditur Militer yang berkewajiban untuk mengeksekusi putusan Hakim Militer. Peradilan Agama, menurut ketentuan pasal 95, 98 dan 103 Undang-Undang Nomor 7 Tahun 1989 juga sudah dapat melaksanakan secara paksa (Eksekusi) atas penetapan dan putusannya termasuk melaksanakan segala macam bentuk sita (beslag). Sementara itu dengan Peraturan, lembaga paksa apa yang dapat diterapkan apabila seluruh tahapan eksekusi, yaitu peneguran melalui atasan secara hierakhi sampai tingkat Presiden, Pejabat TUN tetap tidak melaksanakannya? Sampai saat ini tidak ada. Inilah satusatunya Peradilan dalam sistem peradilan di Indonesia (dari ke-empat lingkungan), yang tidak memiliki lembaga paksa. Untuk itu tidak heran banyak putusan yang tidak dilaksanakan.

2. Rendahnya tingkat kesadaran pejabat TUN dalam menaati putusan pengadilan TUN. Pejabat TUN seringkali tidak menaati hukum, karena biasanya seseorang mematuhi hukum dikarenakan ia takut sanksi yang akan dikenakan apabila ia melanggar hukum 
atau karena ia merasa kepentingan-kepentingannya akan terjamin apabila ia menaati hukum, atau karena ia merasa hukum yang berlaku sesuai dengan nilai-nilai yang berlaku dalam dirinya. Dalam hal ini, pihak yang kalah dalam sengketa tentunya akan merasa bahwa kepentingannya tidak terjamin bila ia menaati putusan pengadilan TUN, sehingga ia lebih memilih untuk tidak mematuhi putusan pengadilan tersebut. Tidak adanya sanksi juga membuat pejabat TUN tidak merasa takut apabila ia tidak menjalankan putusan pengadilan itu. Adanya kepentingan / interest pribadi pejabat eksistensi keputusan TUN yang diterbitkannya dan lemahnya tingkat kesadaran hukum Badan atau Pejabat TUN adalah sangat besar pengaruhnya terhadap dipatuhi atau tidaknya putusan Hakim Peratun, karena secara normatif eksekusi putusan Hakim Peraturan lebih menyandarkan pada kerelaan Pejabat yang bersangkutan untuk melaksanakannya (floating execution). Dengan hanya menyandarkan pada kerelaan, tentu banyak pejabat yang tidak rela bila harus memenuhi putusan, sehingga memilih untuk tidak mematuhi putusan.

3. Tidak adanya pengaturan yang lebih tegas mengenai pelaksanaan putusan PTUN. Seperti yang kita ketahui, ketentuan mengenai eksekusi putusan PTUN telah dimuat dalam pasal 116 Undang-Undang Nomor 5 Tahun 1986 jo Undang-Undang Nomor 9 Tahun 2004 jo UndangUndang Nomor 51 Tahun 2009, yang menyebutkan bahwa pengadilan dapat meminta atasan pejabat Tata Usaha Negara yang bersangkutan atau bahkan presiden untuk 'memaksa' tergugat melaksanakan putusan pengadilan. Hal ini tentu saja tidak dibolehkan terjadi sering-sering karena apabila presiden terlalu sering campur tangan dalam urusan pemaksaan pelaksanaan putusan PTUN maka dikhawatirkan presiden akan kehilangan wibawa sebagai kepala Pemerintahan. Oleh karena itu diperlukan sebuah revisi terhadap Undang-Undang atau peraturan 
pelaksana yang mengatur secara detail pelaksanaan putusan PTUN dan akibatnya bila tidak dipatuhi sehingga di kemudian hari putusan PTUN akan dengan mudah dapat dilaksanakan. Kesimpulannya adalah, ada beberapa kendala yang dihadapi Peradilan Tata Usaha Negara dalam perjalanannya untuk mewujudkan pemerintahan yang bersih dan berwibawa, yaitu satu, tidak adanya lembaga eksekutorial khusus atau lembaga sanksi dalam melaksanakan putusan PTUN, rendahnya kesadaran pejabat TUN dalam mentaati putusan PTUN, dan tidak adanya ketentuan yang lebih rinci mengatur mengenai sanksi apabila putusan tidak dilaksanakan. 


\section{PENUTUP}

Berdasarkan pembahasan diatas dapat disimpulkan bahwa :

Pertama: Pelaksanaan upaya paksa terhadap putusan Pengadilan Tata Usaha Negara dalam memberikan perlindungan hukum kepada masyarakat dilakukan dengan cara :

- Pembayaran sejumlah uang paksa dan/ atau sanksi administratif apabila tergugat tidak bersedia melaksanakan putusan pengadilan yang telah memperoleh kekuatan hukum tetap.

- Apabila tergugat tidak melaksanakan pembayaran sejumlah uang paksa dan/ atau sanksi administratif maka panitera pengadilan memberikan pengumuman pada media massa cetak setempat.

- Di samping diumumkan pada media massa cetak setempat, ketua pengadilan mengajukan hal ini kepada Presiden sebagai pemegang kekuasaan pemerintah tertinggi untuk memerintahkan tergugat melaksanakan putusan pengadilan, dan kepada lembaga perwakilan rakyat untuk menjalankan fungsi pengawasan.

Kedua: Faktor-faktor yang menjadi hambatan terhadap pelaksanaan putusan Pengadilan Tata Usaha Negara dalam memberikan perlindungan hukum kepada masyarakat yaitu sebagai berikut :

- Kurangnya kesadaran pejabat negara sebagai tergugat dalam mematuhi hukum atau mematuhi putusan hakim agar tercipta keadilan dan keharmonisan hukum.

- Kurangnya ketegasan dalam pelaksanaan sanksi hukum dari Pengadilan Tata Usaha Negara untuk memberikan perlindungan hukum kepada masyarakat yang berupa terlaksananya kewajiban dan hak-hak rakyat sebagai penggugat atau tergugat. 


\section{DAFTAR PUSTAKA}

Darmini Roza dan Laurensius Arliman S, Peran Pemerintah Daerah Di Dalam Melindungi

Hak Anak Di Indonesia, Masalah-Masalah Hukum, Volume 47, Nomor 1, 2018. https://doi.org/10.14710/mmh.47.1.2018.10-21

Laurensius Arliman S, Peranan Metodologi Penelitian Hukum di Dalam Perkembangan Ilmu

Hukum di Indonesia, Soumatera Law Review, Volume 1, Nomor 1, 201. http://doi.org/10.22216/soumlaw.v1i1.3346.

Laurensius Arliman S, Peran Badan Permusyawaratan Desa di Dalam Pembangunan Desa

dan Pengawasan Keuangan Desa, Padjadjaran Journal of Law, Volume 4, Nomor 3, 2017. https://doi.org/10.15408/jch.v4i2.3433.

Laurensius Arliman S, Penanaman Modal Asing Di Sumatera Barat Berdasarkan Undang-

Undang Nomor 25 Tahun 2007 Tentang Penanaman Modal, Supremasi Hukum, Volume 1, Nomor 1, 2018. http://dx.doi.org/10.36441/hukum.v1i01.102.

Laurensius Arliman S, Memperkuat Kearifan Lokal Untuk Menangkal Intoleransi Umat

Beragama Di Indonesia, Ensiklopedia of Journal, Volume 1, Nomor 1, 2018, https://doi.org/10.33559/eoj.v1i1.18.

Laurensius Arliman S, Perkawinan Antar Negara Di Indonesia Berdasarkan Hukum Perdata

Internasional, Kertha Patrika, Volume 39, Nomor 3, 2017, https://doi.org/10.24843/KP.2017.v39.i03.p03.

Laurensius Arliman S, Partisipasi Masyarakat Di Dalam Pengelolaan Uang Desa Pasca

Undang-Undang Nomor 6 Tahun 2014 Tentang Desa, Jurnal Arena Hukum, Volume 12, Nomor 2, 2019, https://doi.org/10.21776/ub.arenahukum.2019.01202.5.

Laurensius Arliman S, Mewujudkan Penegakan Hukum Yang Baik Di Negara Hukum

Indonesia, Dialogica Jurnalica, Volume 11, Nomor 1, 2019, https://doi.org/10.28932/di.v11i1.1831. 
Laurensius Arliman S, Mediasi Melalui Pendekatan Mufakat Sebagai Lembaga Alternatif Penyelesaian Sengketa Untuk Mendukung Pembangunan Ekonomi Nasional, UIR Law Review, Volume 2, Nomor 2018, https://doi.org/10.25299/uirlrev.2018.vol2(02).1587

Laurensius Arliman S, Peranan Filsafat Hukum Dalam Perlindungan Hak Anak Yang Berkelanjutan Sebagai Bagian Dari Hak Asasi Manusia, Doctrinal, Volume 1, Nomor $2,2016$.

Laurensius Arliman S, Ni Putu Eka Dewi, Protection of Children and Women's Rights in Indonesia through International Regulation Ratification, Journal of Innovation, Creativity and Change Volume 15, Nomor 6, 2021.

Laurensius Arliman S, Gagalnya Perlindungan Anak Sebagai Salah Satu Bagian Dari Hak Asasi Manusia Oleh Orang Tua Ditinjau Dari Mazhab Utilitarianisme, Jurnal Yuridis, Volume 3, Nomor 2, 2016, http://dx.doi.org/10.35586/.v3i2.180.

Laurensius Arliman S, Tantangan Pendidikan Kewarganegaraan Pada Revolusi 4.0, Jurnal Ensiklopedia Sosial Review, Volume 2, Nomor 3, 2020.. 